\title{
The efficacy of fetal neural cell aggregates and their combination with fetal liver stromal cells to reduce brain damage after intracerebral hemorrhage in rats
}

\author{
Zolotko K. ${ }^{1}$, Sukach O. ${ }^{1,2}$, Kompaniets A. ${ }^{1}$ \\ ${ }^{1}$ Institute for Problems of Cryobiology and Cryomedicine, National Academy of Sciences of Ukraine, Kharkiv, Ukraine \\ ${ }^{2}$ H. S. Skovoroda Kharkiv National Pedagogical University, Kharkiv, Ukraine \\ Corresponding author's e-mail: zolotkokm@gmail.com
}

\section{ABSTRACT}

Patients with intracerebral hemorrhage have frequent complications and high mortality. There are currently no effective treatments for this disease. We investigated the effect of the use of cryopreserved aggregates of neural cells in combination with fetal liver stromal cells on the reduction of rat brain injury after intracerebral hemorrhage.

METHODS. Intracerebral hemorrhage (ICH) was modeled in rats by stereotactic administration of $0.2 \mathrm{U}$ of collagenase type IV into the striatum. Neural cells were obtained from brain and stromal cells (SCS) - from the liver of rat fetuses of $15 \mathrm{dpc}$. The suspension of neural cell aggregates (NCAs) alone or in combination with fetal liver stromal cells was injected into the lateral ventricle.

The level of lipid peroxidation was determined by the thiobarbituric acid test. The degree of brain cells injury after ICH was determined by the activity of lactate dehydrogenase in blood serum. To assess the intensity of adverse factors and the regenerative potential of different variants of cell therapy, the area of the lost striatum in the rat brain and the average distance from the border of the lesion to the nearest neurons were determined.

RESULTS. Combined transplantation of NCAs with fetal liver SCs in rats with ICH was found to reduce malonic dialdehyde concentration and lactate dehydrogenase activity more effectively than NCAs alone, indicating inhibition of lipid peroxidation and reduction of cell injury after intracerebral hemorrhage as a result of the addition of SCs. There was shown a significant decrease in the area of lost striatum in both experimental groups. The single administration of NCAs reduced the distance from the lesion border to the nearest neurons the most, indicating the best conditions for survival and/or regeneration of neurons close to the lesion compared to controls.

CONCLUSIONS. Administration of NCAs, both alone and in combination with fetal liver SCs, reduces the intensity of oxidative stress, preserves the intact striatum tissue, and increases the number of neurons near the brain lesion in intracerebral hemorrhage in rats. The co-transplantation of fetal liver SCs helps to inhibit lipid peroxidation more effectively.

KEY WORDS: intracerebral hemorrhage; neural cells aggregates; fetal liver stromal cells; stereotaxis

Intracerebral hemorrhage (ICH), which causes approximately $15 \%$ of all strokes, is accompanied by severe complications and high mortality. Despite some advances in treatment, there has been very little progress in preventing long-term complications of this disease. Only $46 \%$ of patients with ICH survive more than one year and $29 \%$ live more than 5 years [1]. Surviving patients suffer from severe and prolonged neurological dysfunction. In the early period of $\mathrm{ICH}$, the main traumatic factor is the compression of the brain tissue due to the expansion of the hematoma.
At the same time, the hematoma is the cause of secondary brain injury. Therefore, it is necessary to develop new approaches to treatment, which are aimed at reducing edema and inflammation and lead to improved health, faster rehabilitation of patients and are associated with effective prevention of complications after ICH.

One of such approaches may be cell therapy using neural progenitor cells, which can differentiate into neurons, glial cells and produce growth factors [2, 3]. In this case, as shown by our previous studies [4], due 
to the greater survival of cells, the administration of neural cells (NCs) in the aggregates was more effective than the infusion of these cells in the suspension. Their co-transplantation with multipotent mesenchymal stromal cells, which have the ability to suppress the immune response and protect against excessive inflammatory reactions, can also increase the NCs effectiveness [2,5].

The PURPOSE of the study was to determine the effectiveness of cryopreserved neural cells in aggregates (NCAs) and combinations of NCAs with fetal liver stromal cells (SCs) after modeling intracerebral hemorrhage in rats.

\section{MATERIALS AND METHODS}

The experiments were performed in accordance with the Law of Ukraine "On Protection of Animals from Cruelty" (№ 3447-IV) in compliance with the requirements of the Bioethics Committee of the Institute of Cryobiology and Cryomedicine of NAS of Ukraine (Kharkiv), consistent with the European Convention on protection of vertebrates used for experimental and other scientific purposes (Strasbourg, 1986).

The experiments were performed on 30 white outbred male rats 11-13 months old weighing 250-400 g. All animals underwent $\mathrm{ICH}$ modeling and were divided into 4 groups: 1 - control group $1(n=7)-$ no administration of any substances after surgery; 2 - control group 2 $(n=9)$ - the injection of $30 \mu \mathrm{L}$ of DMEM/F12 medium (Sigma, USA) into the lateral ventricle; 3 - group "NCAs" $(n=7)$ - the administration of NCAs suspension containing approximately $1,5 \cdot 10^{6}$ cells in $30 \mu \mathrm{L}$ of DMEM/F12 medium; 4 - group "NCAs/SCs" $(n=7)$ - the injection of cell suspension containing $1,5 \cdot 10^{6}$ neural cells in the aggregates and $1 \cdot 10^{6}$ fetal liver SCs in $45 \mu \mathrm{L}$ of DMEM/F12 medium.

ICH modeling was performed under general anesthesia by intraperitoneal injection of Propofol $15 \mathrm{mg} / \mathrm{kg}$ (Daewon Pharmaceutical Co. Ltd., Korea/Switzerland) and Xylazine $5 \mathrm{mg} / \mathrm{kg}$ (Biowet, Poland). Rats were injected with $0.2 \mathrm{U}$ collagenase type IV (Sigma-Aldrich, USA) in $1 \mu \mathrm{L}$ of saline into the striatum through a needle with a diameter of $0.47 \mathrm{~mm}$ by stereotaxic surgery. Stereotaxic coordinates of collagenase administration: anteroposterior $-0.2 \mathrm{~mm}$ in front of the bregma, mediolateral -3.0 $\mathrm{mm}$ on the left of the bregma, depth $-6 \mathrm{~mm}$. 5 minutes after injection, the needle was removed and the wound was sutured [6]. The next day after ICH modeling, $30 \mu \mathrm{L}$ of DMEM/F12 medium (Sigma, USA) without cells in group 2 or with cells in groups 3 and 4 was injected into the lateral ventricle of the brain. Stereotactic coordinates: anteroposterior $-0.9 \mathrm{~mm}$ behind the bregma, mediolateral $-1.4 \mathrm{~mm}$ to the right of the bregma, depth $3.4 \mathrm{~mm}$. The calculation of the required number of transplanted cells was performed on the basis of previous studies $[2,7,8]$. The difference in the volume of suspensions administered to the rats of the experimental groups is explained by the additional number of fetal liver SCs in group 4.

Neural cells were isolated from the brain of rat fetuses of 15-16 dpc by vibration [9]. 4 pregnant female rats were used. The number of fetuses per female was 8-9. In order to avoid the effect of anesthetics on the results of the experiment, euthanasia was performed by decapitation. To form aggregates, freshly obtained NCs were cultured for 3 hours in 24-well plates at a concentration of $2 \cdot 10^{6} \mathrm{cells} / \mathrm{mL}$ in DMEM/F12 medium supplemented with $10 \%$ serum of adult rats [10]. The medium was not replaced. At the same time, about $75 \%$ of cells formed aggregates [11], with a diameter of 50 to $200 \mu \mathrm{m}$ (Fig. 1). Thus, the suspension of NCAs after $5 \mathrm{~min}$ of centrifugation at $100 \mathrm{xg}$ contained approximately $5 \cdot 10^{7}$ cells $/ \mathrm{mL}\left(1,5 \cdot 10^{6}\right.$ cells $\left./ 30 \mu \mathrm{L}\right)$.

Stromal cells were obtained from the liver of rat fetuses of 15-16 dpc. The liver was isolated, placed in $0.25 \%$ trypsin solution (Sigma, USA), incubated for 3 minutes at $37^{\circ} \mathrm{C}$ and then transferred to DMEM/ F12 medium supplemented with fetal bovine serum $10 \%$ (FBS, Sigma, Germany) and disaggregated into single cells suspension by vibration [12]. The resulting cell suspension was filtered through a nylon filter with a pore diameter of $15 \mu \mathrm{m}$ and washed from trypsin by centrifugation (5 min at $100 \mathrm{xg}$ ). The cell pellet was suspended in DMEM/F12 medium containing $0.6 \%$ glucose, $2 \mathrm{mM}$ glutamine, $100 \mathrm{U} / \mathrm{mL}$ penicillin and $100 \mu \mathrm{g} / \mathrm{mL}$ streptomycin supplemented with $10 \% \mathrm{FBS}$. The viability and number of cells were counted in a Goryaev's chamber. The cells were seeded at a concentration of $5 \cdot 10^{5}$ cells $/ \mathrm{mL}$ and cultured in DMEM/F12 medium enriched with $0.6 \%$ glucose, $2 \mathrm{mM}$ glutamine, $100 \mathrm{U} / \mathrm{mL}$ penicillin and $100 \mu \mathrm{g} / \mathrm{mL}$ streptomycin supplemented with $10 \% \mathrm{FBS}$. Cultivation was performed in a $\mathrm{CO}_{2}$ incubator $\left(37^{\circ} \mathrm{C}, 5 \% \mathrm{CO}_{2}, 80 \%\right.$ humidity) replacing the nutrient medium every 3 days. When the monolayer reached $80 \%$ confluency, the cells were detached using a mixture of $0.25 \%$ trypsin solution with Versene solution (1:1) and subcultured in a ratio of 1:3. After the third passage, the cells were detached and cryopreserved. The obtained cells (Fig. 2) were defined as stromal cells of the fetal liver. The standard protocol for multipotent mesenchymal stromal cells isolation was used based on the fact that the fetal liver at 15-16 dpc contains a significant number of cells of mesenchymal origin, which provide the microenvironment of hematopoietic stem cells and liver stem cells $[13,14]$.

Cryopreservation of NCAs and SCs was performed in DMEM/F12 medium with $0.6 \%$ glucose, $2 \mathrm{mM}$ glutamine supplemented with $10 \%$ FBS

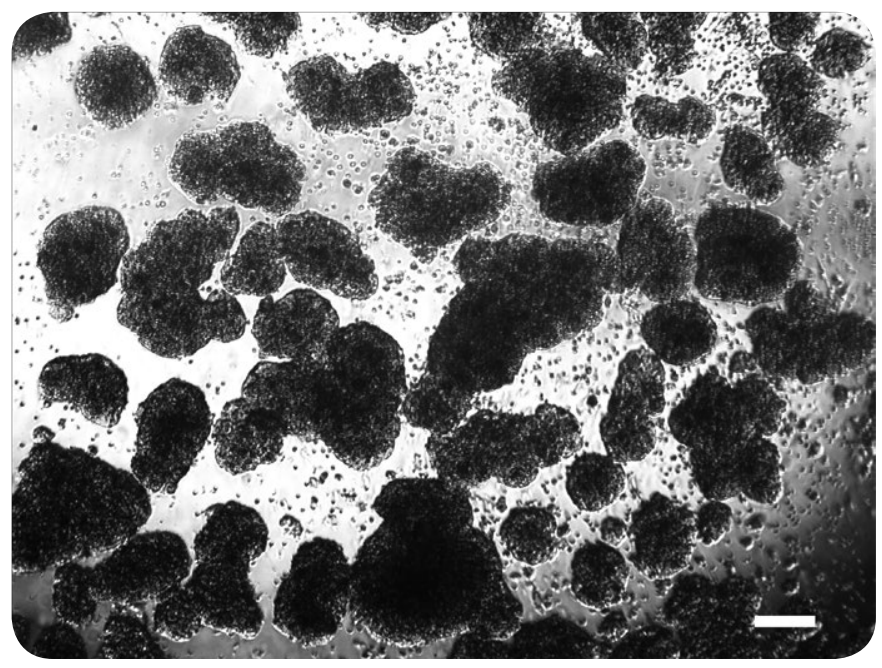

Fig. 1. Micrograph of neural cells aggregates from the brain of $15 \mathrm{dpc}$ rat fetuses, formed after 3 hours of cultivation. Light microscopy; scale bar $-100 \mu \mathrm{m}$.

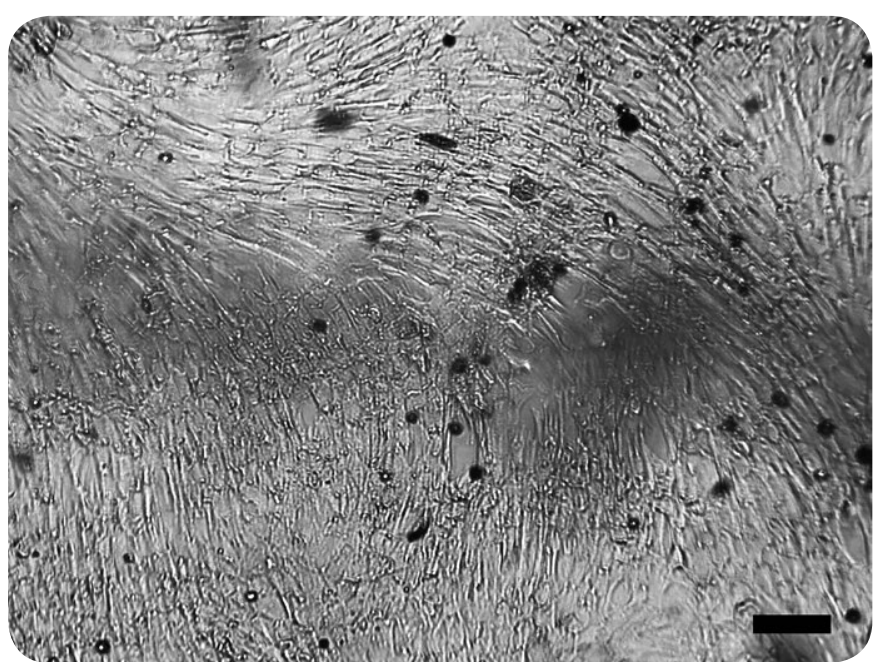

Fig. 2. Microphotograph of the culture of rat fetal liver stromal cells, the $3^{\text {rd }}$ passage. Light microscopy; scale bar $-100 \mu \mathrm{m}$. 
and $10 \%$ DMSO at a cooling rate of $1{ }^{\circ} \mathrm{C} / \mathrm{min}$ to $-80{ }^{\circ} \mathrm{C}$, after which the cells were transferred to liquid nitrogen. Thawing of NCAs and SCs was performed in a water bath at $+40^{\circ} \mathrm{C}, \mathrm{DMSO}$ was washed by centrifugation at $100 \mathrm{xg}$ for 5 minutes. The number of SCs in $1 \mathrm{~mL}$ of pellet was counted and diluted with DMEM/F12 medium to a concentration of $6.7 \cdot 10^{7} \mathrm{cell} / \mathrm{s} / \mathrm{mL}$ $\left(1 \cdot 10^{6}\right.$ cells per $\left.15 \mu \mathrm{L}\right)$. Before determining the number of cells in NCAs, they were disaggregated into single NCs by vibration [9]. The number of SCs and NCs was counted and their viability was assessed in a Goryaev chamber after staining with Trypan blue.

The content of malonic dialdehyde (MDA) and other thiobarbituric acid (TBA) products was determined to assess the content of secondary products of lipid peroxidation in the serum. Serum lactate dehydrogenase (LDH) activity was determined to assess the brain cell injury after $\mathrm{ICH}$. Blood sampling was performed before the experiment, on the $1^{\text {st }}$ day (before injections into the brain ventricle), as well as on the $2^{\text {nd }}, 7^{\text {th }}$ and $14^{\text {th }}$ day after ICH modeling by sampling blood from the tail vein. We did not perform the blood sampling later due to the fact that according to the literary data, the maximum levels of MDA are reached on the $3^{\text {rd }}$ day after $\mathrm{ICH}$ and they return to normal levels by the $14^{\text {th }}$ day $[15,16]$.

The content of TBA products in the serum was determined by the method [17], which is based on colorimetric measurement of the absorption intensity of the MDA complex with thiobarbituric acid. $0.3 \mathrm{~mL}$ of serum, and then $1 \mathrm{~mL}$ of $0.6 \%$ TBA were added to $3 \mathrm{~mL}$ of $1.4 \% \mathrm{H}_{3} \mathrm{PO}_{4}$ $(\mathrm{pH}=2.0)$. The samples were boiled in a water bath in closed tubes for 45 minutes. After cooling, $4 \mathrm{~mL}$ of butanol was added to the samples, mixed thoroughly and centrifuged for 10 minutes at $1500 \mathrm{xg}$. The butanol fraction was collected and analyzed on a Cary-50 spectrophotometer (Varian, Australia) at 535 and $580 \mathrm{~nm}$ compared to the control sample. The content of TBA products was calculated by the following formula:

$$
\mathrm{C}=(\mathrm{D} 535-\mathrm{D} 580) \times 13.3 / 0.156 \times 1.0 \text {; }
$$

where D535 and D580 - the absorption of the samples at the respective wavelengths, 13.3 - serum dilution factor, 0.156 - molar extinction coefficient, $\mu \mathrm{M}^{-1} \cdot \mathrm{cm}^{-1} ; 1.0$ - optical distance, $\mathrm{cm}$

The determination of lactate dehydrogenase (LDH) activity was performed using a standard kit of reagents (Erba Lachemas. r.o, Czech Republic) according to the instructions. Following reagents were used for analysis: "R1", which contained Tris buffer $100 \mathrm{mM} / \mathrm{L}(\mathrm{pH}=7.5)$ and pyruvate $2.0 \mathrm{mM} / \mathrm{L}$; and reagent "R2" - NADH $1.66 \mathrm{mM} / \mathrm{L}$. The sample $(20 \mu \mathrm{L})$ was added to the working solution $(1.0 \mathrm{~mL})$, mixed, incubated for 1 min at $37^{\circ} \mathrm{C}$, then the absorbance was measured after 1,2 and 3 min, and the average absorption difference per minute $(\delta A)$ was calculated by the formula:

$$
\mathrm{LDH}(\mathrm{U} / \mathrm{L})=\delta \mathrm{A} \text { (sample) } \times \mathrm{F} \text {, }
$$

where $F$ is the conversion factor equal to 11496 .

The rats were decapitated on the $42^{\text {nd }}$ day of the experiment under anesthesia with $15 \mathrm{mg} / \mathrm{kg}$ Propofol (Daewon Pharmaceutical Co. Ltd., Korea/Switzerland) and $5 \mathrm{mg} / \mathrm{kg}$ Xylazine (Biowet, Poland). The rat brain was fixed in $4 \%$ formaldehyde solution (O.L.KAR, Ukraine). After fixation, the brain was dehydrated in gradually increasing concentrations of ethanol, after which the alcohol was removed with xylene in increasing concentrations. The xylene was gradually replaced with paraffin in a thermostat until complete removal. Paraffin blocks were formed and then cut on a microtome into sections about $10 \mu \mathrm{m}$ thick. Paraffin and xylene were removed from the sections. To detect neurons and perform morphometric studies, sections were stained with Nissl methylene blue (Khimreaktiv, Ukraine). Morphological examination was performed on a microscope Biogenic LED Trino (Sigeta, China) with a camera MCMOS 5100 (Sigeta, China). Morphometric analysis was performed using the software LSM Image Examiner (Zeiss, Germany): the area of the lost striatum $\left(\mathrm{mm}^{2}\right)$ and the average distance from the border of the lesion to the nearest neurons $(\mu \mathrm{m})$ were measured.

The lost striatum area (LSA) was calculated based on a modified method [6]. The area of the striatum both on the affected side (ipsilateral) and on the opposite unaffected side (contralateral) were measured (Fig. 3). The area of the contralateral striatum was subtracted from the area

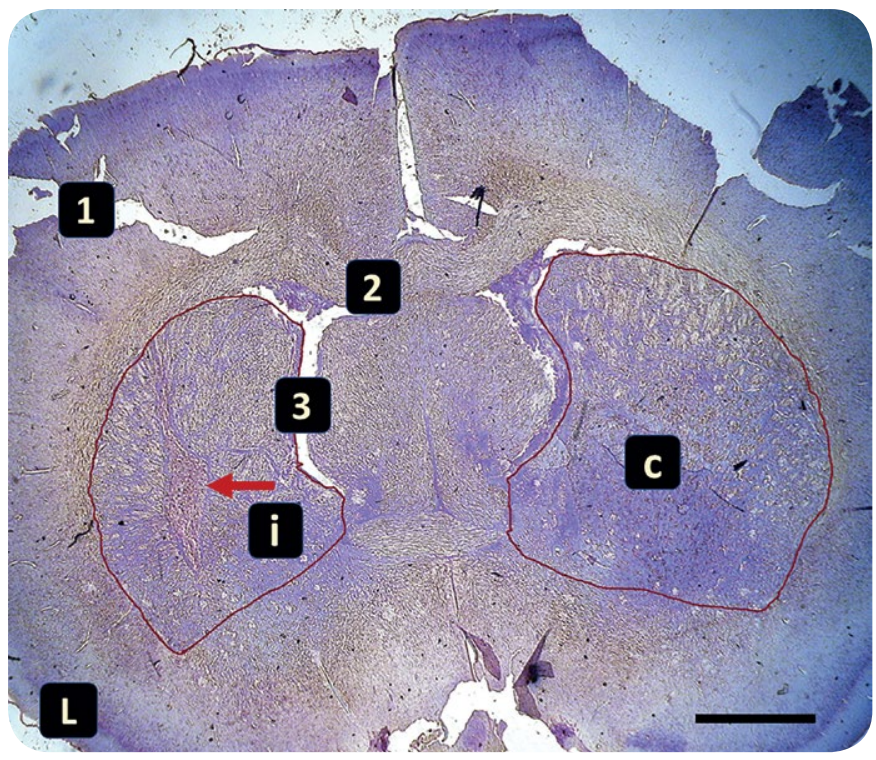

A Fig. 3. The microphotograph of the rat brain sections, illustrating a method of measuring the maximum area of ipsilateral and contralateral striatums on the $42^{\text {nd }}$ day after hemorrhage. Nissl staining, scale bar - $1000 \mu \mathrm{m}$. Notes: 1 - the cerebral cortex; 2 - corpus callosum; 3 - lateral brain ventricles; $i$ - ipsilateral striatum; $c$ - contralateral striatum; $L$ - left hemisphere of the brain; arrow indicates damaged area.

of the ipsilateral striatum after subtracting from the last area of the lesion zone. To make the comparison with other parameters easier, the percentage of LSA from the area of the contralateral striatum was calculated.

The average distance from damage border to the nearest neurons (DDNN) reflects the state of the intercellular space near ICH during the experiment up to the $42^{\text {nd }}$ day. Chronic inflammation, hypoxia and toxic effects of hemoglobin degradation products lead to the death of many neurons, which increases DDNN. On the other hand, the probable migration of endogenous or transplanted neural cells and their differentiation into neurons may reduce DDNN. Thus, this method makes it possible to comprehensively assess the reduction of the duration and intensity of adverse factors, as well as the regenerative potential of different variants for cell therapy. To determine DDNN, the distance from the border of the lesion zone to the five nearest neurons was measured in 3 points of the lesion border at a magnification of $\times 40$. The result in one animal was determined as the mean of 15 measured distances.

SPSS (IBM, USA) and MS Excel (Microsoft, USA) software were used for statistical analysis. Due to the small sample size, we used non-parametric statistics. The mean value was estimated by the median. The Dunnett's correction which is a more powerful analogue of the Bonferroni correction, was applied for multiple comparisons (more than 2 groups). In this case, we indicated the significance level a, considering the correction that takes into account the number of comparisons. The Kruskal-Wallis test was used to assess the statistical significance of the difference between the independent groups. This test, however, does not provide information on which groups differ in pairwise comparison. Thus, in the presence of significant differences in the Kruskal-Wallis test, pairwise comparisons were performed according to Dunn's test, which takes into account the number of compared groups [18]. In many tests, animals were observed in the dynamics, which reflects the change in performance over time in the same groups. In this case, the statistically significant changes were determined by Friedman's test. This criterion does not provide information on which time intervals had significant differences. The Friedman-Conover Test was used for this purpose [19]. In all tests, the significance level was taken as $\alpha=0.05$ with corrections for multiple comparisons. 


\begin{tabular}{|c|c|c|c|c|c|}
\hline & n & MIN (\%) & Q25 (\%) & Q50 (\%) & Q75 (\%) \\
\hline NCs & 7 & 19.0 & 27.0 & 32.0 & 38.0 \\
\hline NCAs & 7 & 51.0 & 66.8 & 77.5 & 82.8 \\
\hline SCs & 7 & 48.0 & 68.0 & 75.0 & 79.0 \\
\hline
\end{tabular}

The viability of NCs, NCAs and MSCs after cryopreservation was $32 \%$, $78 \%$ and $75 \%$, respectively (Table 1). The viability of NCs in aggregates was higher than in NCs in suspension ( $p=0.001)$, Mann-Whitney test.

When determining the MDA and other TBA active products in the blood of rats before $\mathrm{ICH}$, a minimal difference was found between the groups (interquartile range was $0.8 \mathrm{mM} / \mathrm{L}$, or $16 \%$ of the intergroup median). In the $1^{\text {st }}$ and $2^{\text {nd }}$ control groups there were significant changes according to the Friedman test and an increase in the level of MDA on the $2^{\text {nd }}$ day compared with the values before ICH. In the NCAs and NCAs/SCs groups, changes in the dynamics were not significant (Fig. 4).

On the $2^{\text {nd }}$ day, when comparing all groups with each other in the Kruskal-Wallis test, statistically significant differences $(p=0.003)$ were revealed. Significantly lower concentrations of MDA were observed in the NCAs and NCAs/SCs groups than in the $2^{\text {nd }}$ control group ( $p=0.014$ and $p=0.0001$, respectively; $a=0.017$ ) (Fig. 5).

On the $7^{\text {th }}$ day, when comparing all groups with each other in the Kruskal-Wallis test the statistically significant differences $(p=0.006)$ were revealed. Significantly lower concentrations of MDA were observed in the NCAs and NCAs/SCs groups than in the $2^{\text {nd }}$ control group $(p=0.006$ and $p=0.0005$, respectively; $a=0.017$ ) (Fig. 6 ). In the NCAs/SCs group there was also a tendency to a lower concentration of MDA than in the $1^{\text {st }}$ control group ( $p=0.034 ; a=0.017$ ) (Fig. 6).

On the $14^{\text {th }}$ day, when comparing all groups with each other in the Kruskal-Wallis test, statistically significant differences $(p=0.008)$ were revealed. In the NCAs/SCs group, a significantly lower concentration of MDA was observed than in the $2^{\text {nd }}$ control group $(p=0.0006 ; a=0.017)$

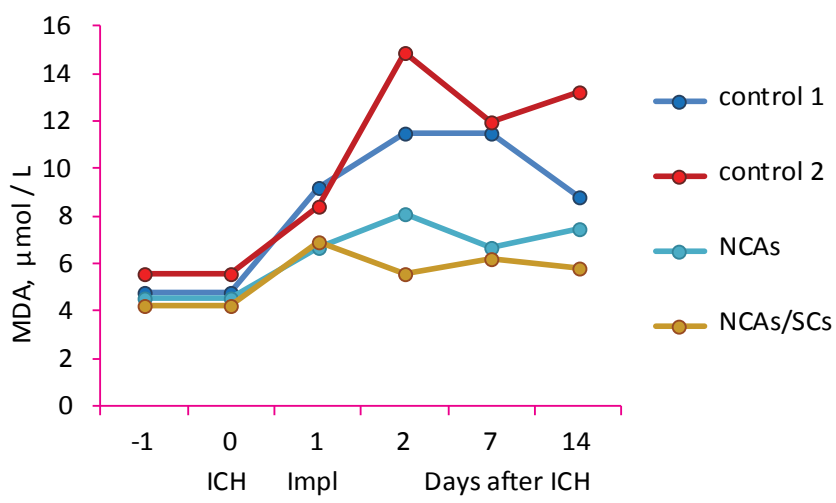

A Fig. 4. The assessment of the dynamics of lipid peroxidation based on the results of determining the concentration of malonic dialdehyde (MDA) in the serum of rats of experimental groups. $\mathrm{ICH}$ - modeling of intracerebral hemorrhage; Inj - injections of cells or DMEM/F12 medium.

Note:

\# - represents significant changes in the concentration of MDA over the observation period $(p<0.05)$, Friedman test;

* - represents significant increase in the level of MDA compared to results before $\mathrm{ICH}(p<0.005 ; \boldsymbol{a}=0.005)$, Friedman-Conover test
(X̉) $(\%)$

75.0
Table 1. Cells viability distribution characteristics after cryopreservation. Notes: $n$ - the number of cells viability tests; $Q 25, Q 50$ and $Q 75$ are the $1^{\text {st }}, 2^{\text {nd }}$ and the $3^{\text {rd }}$ quartiles, respectively; Min and Max are minimal and maximal values; $\dot{\boldsymbol{X}}-$ is the arithmetical mean.

(Fig. 7). Rats in the NCAs group tended to have a lower concentration of MDA than in the $2^{\text {nd }}$ control group $(p=0.062)$. The tendency to a higher concentration of MDA in the $2^{\text {nd }}$ control compared with the $1^{\text {st }}$ one $(p=0.065)$ may be a consequence of the trauma of the additional operation for the cell transplantation, which is expressed in a greater activity of lipid peroxidation.

The decrease in MDA levels in the NCAs and NCAs/SCs groups compared with the $2^{\text {nd }}$ control group from the $2^{\text {nd }}$ day to the end of experiment indicates a strong antioxidant effect of the injected cells at the beginning

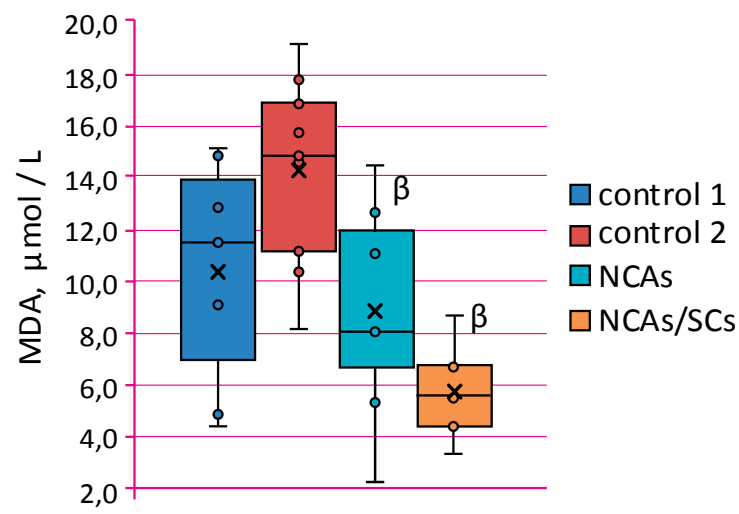

Fig. 5. The concentration of malonic dialdehyde (MDA) in the serum of rats of experimental groups on the $2^{\text {nd }}$ day after $\mathrm{ICH}$.

Notes: $\beta$ - represents significant differences from the $2^{\text {nd }}$ control group $(p<0.017)$, Dunn's test.

The box with whisker plots indicates the characteristics of the distributions: line inside - the median (the $2^{\text {nd }}$ quartile); lower and upper boundaries- the $1^{\text {st }}$ and the $3^{\text {rd }}$ quartiles, respectively; lower and upper whiskers - minimum and maximum value, respectively; $x$ - the average sample.

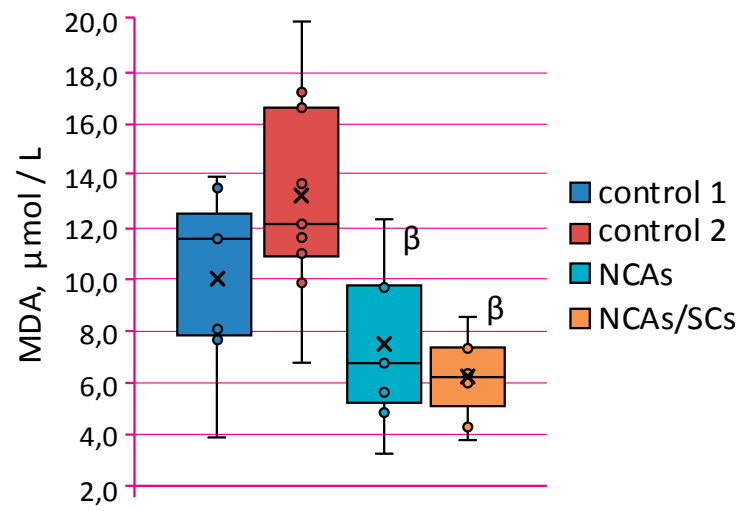

Fig. 6. The concentration of malonic dialdehyde (MDA) in the serum of rats of experimental groups on the $7^{\text {th }}$ day after $\mathrm{ICH}$. Notes: $\beta$ - represents significant difference from the $2^{\text {nd }}$ control group $(p<0.017)$, Dunn's test. Types of the box with whisker plots are the same as on Fig. 5. 


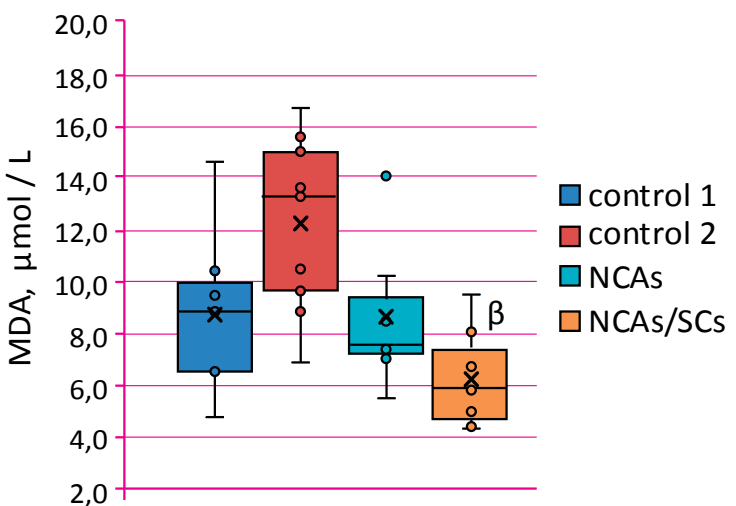

$\boldsymbol{\Lambda}$

Fig. 7. The concentration of malonic dialdehyde (MDA) in the serum of rats of experimental groups on the $14^{\text {th }}$ day after ICH. Notes: $\beta$ - represents significant difference from the $2^{\text {nd }}$ control group $(p=0.0006)$, Dunn's test. Types of box with whisker plots are the same as on Fig. 5.

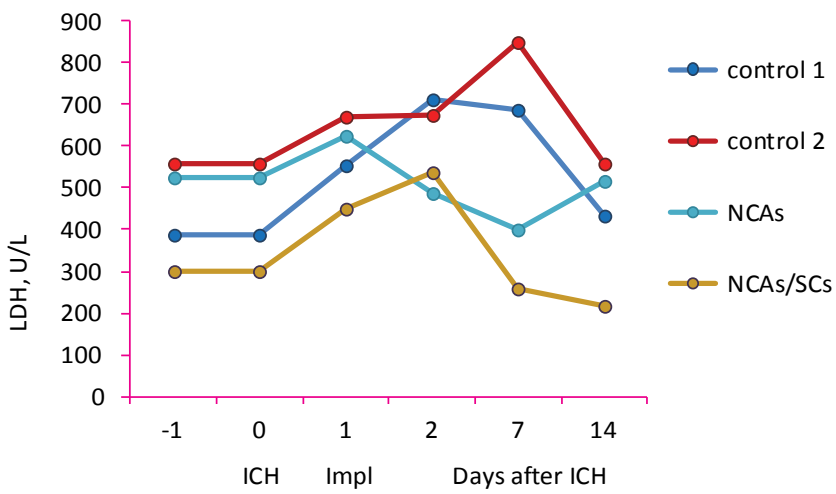

Fig. 8. The dynamics of brain cell damage according to the results of determining the activity of lactate dehydrogenase (LDH) in the serum of rats of experimental groups. ICH - modeling of intracerebral hemorrhage; Inj - injection of cells or DMEM/F12 medium.

Notes: \# - represents significant changes in the concentration of $L D H$ over the observation period $(p<0.05)$, Friedman test; ${ }^{*}$ - represents significant increase in the level of $\mathrm{LDH}$ compared to results before $\mathrm{ICH}$ $(p<0.005 ; a=0.005)$, Friedman-Conover test.

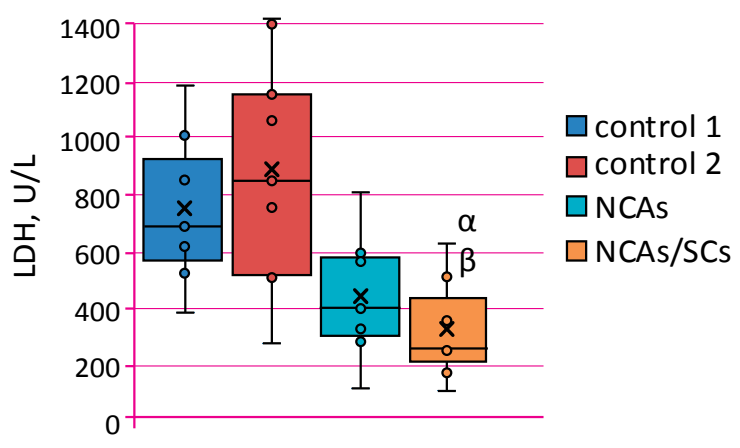

Fig. 9. The activity of lactate dehydrogenase (LDH) in the serum of rats on the $7^{\text {th }}$ day after $\mathrm{ICH}$.

Notes: a - represents significant difference from the $1^{\text {st }}$ control group $(p=0.01)$, Dunn's test; $\beta$-represents significant difference from the $2^{\text {nd }}$ control group $(p=0.003)$, Dunn's test.

Types of box with whisker plots are the same as on Fig. 5 .

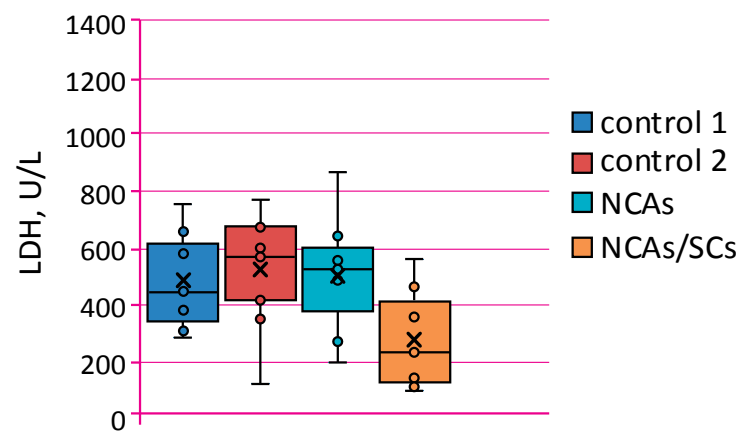

A Fig. 10. The activity of lactate dehydrogenase (LDH) in the serum of rats of experimental groups on the $14^{\text {th }}$ day after ICH Note: types of box with whisker plots are the same as on Fig. 5

of treatment, which prevented increased lipid peroxidation in the NCAs and NCAs/SCs groups.

When determining LDH activity in the blood of rats before $\mathrm{ICH}$, a relative homogeneity of groups (interquartile range was $78 \mathrm{U}$, or $18 \%$ of the intergroup median) was found. On the $7^{\text {th }}$ day after ICH modeling, there was a significant increase in LDH activity in the $2^{\text {nd }}$ control group compared with the results before ICH (Fig. 8), which indicates a significant increase in neural cell damage in rats of this group.

On the $7^{\text {th }}$ day when comparing all groups with each other in the Kruskal-Wallis test, statistically significant differences $(p=0.008)$ were revealed. Significantly less LDH activity was observed in the NCAs/SCs group than in the $1^{\text {st }}$ and $2^{\text {nd }}$ control groups $(p=0.010$ and $p=0.003$, respectively; $a=0.017$ ) (Fig. 9), which indicates a significant decrease in the intensity of cell damage during the $1^{\text {st }}$ week when using NCAs in combination with SCs, even compared with the control group, where no additional surgery was performed. In addition, in the NCAs group there was also a tendency to lower LDH activity than in the $2^{\text {nd }}$ control group $(p=0.040 ; a=0.017)$.

On the $14^{\text {th }}$ day in the $1^{\text {st }}$ and $2^{\text {nd }}$ control groups there was a tendency to spontaneous normalization of LDH activity in comparison with the results of the $7^{\text {th }}$ day (Fig. 10). When comparing all groups with each other, the Kruskal-Wallis test found no significant differences $(p=0.083)$. When comparing between the groups, there was a tendency to lower LDH activity in the NCAs/SCs group than in the $2^{\text {nd }}$ control group $(p=0.011$; $a=0.017$, but the result is not significant according to the Kruskal-Wallis test. There was also a tendency to lower LDH activity in the NCAs/SCs group than in the $1^{\text {st }}$ control group $(p=0.054)$. In addition, LDH activity in the NCAs/SCs group tended to be lower than in the NCAs group $(p=0.057)$. These trends may be due to the greater effectiveness of the combination of NCAs with SCs than a single administration of NCAs to reduce brain cell damage after $\mathrm{ICH}$.

A significant decrease in LDH activity in both experimental groups on the $7^{\text {th }}$ day, as well as a decrease in LDH in the NCAs/SCs group on the $14^{\text {th }}$ day indicates the effectiveness of cryopreserved NCAs, as well as their combination with fetal liver SCs to reduce cell damage after ICH. It is also important that the SCs prolonged therapeutic effect of the NCAs.

\section{MORPHOLOGICAL STUDIES}

Morphological examination of all rats with $\mathrm{ICH}$ revealed the inclusion of the pigment hemosiderin, which was in the form of yellow-green granules formed as a result of the release and binding of iron during the destruction of erythrocytes in brain tissue after ICH [20] (Fig. 11). The detection of hemosiderin inclusions was necessary to determine the average distance from the lesion to the nearest neurons, which also reflects the thickness of glial scar. 


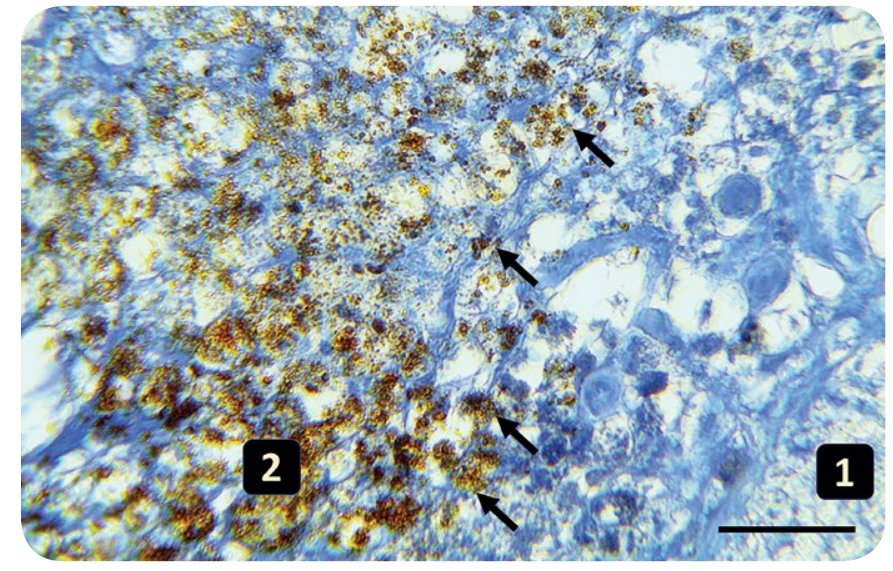

A

Fig. 11. Microphotograph of hemosiderin inclusions in the striatum of rats of the $1^{\text {st }}$ control group on the $42^{\text {nd }}$ day after $\mathrm{ICH}$ : 1 - the intact area of the striatum; 2 - the damaged area of the striatum. The arrows indicate hemosiderin granules. Nissl staining, scale bar - $50 \mu \mathrm{m}$.

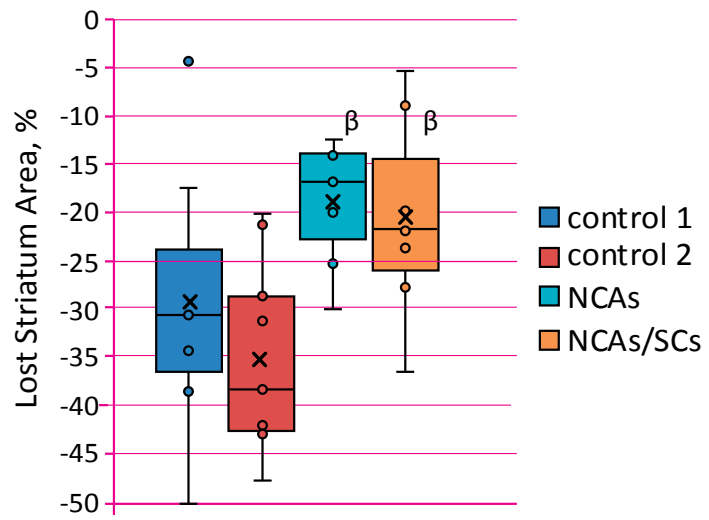

Fig. 12. The reduction of the striatum loss in rats of experimental groups on the $42^{\text {nd }}$ day after $\mathrm{ICH}, \%$.

Notes: $\beta$ - represents significant difference from the $2^{\text {nd }}$ control group $(p<0.017)$, Dunn's test.

Types of box with whisker plots are the same as on Fig. 5 .

As a result, on the $42^{\text {nd }}$ day after $\mathrm{ICH}$, the areas of damage are formed in the striatum of animals [21]. The area of damage did not accurately reflect the severity of brain injury in ICH because it did not take into account the dilatation of the lateral ventricle on the affected side. The dilatation of the ventricles was due to the contraction of the striatum tissue by the glial scar formed in the area of brain injury and around it. Thus, to estimate the volume of the lost striatum, it was more appropriate to calculate the maximum of lost striatum area (LSA).

When comparing all groups with each other in the Kruskal-Wallis test, the presence of statistically significant differences $(p=0.021)$ was found. On the $42^{\text {nd }}$ day, rats of the NCAs and NCAs/SCs groups showed a significantly smaller percentage of LSA than in the $2^{\text {nd }}$ control group $(p=0.002$ and $p=0.009$, respectively; $a=0.017$ ) (Fig. 12), indicating the effectiveness of cryopreserved cells in both groups to reduce striatum loss after $\mathrm{ICH}$. Probably, the effect of cells provided by the production of growth factors that have anti-inflammatory effects and can promote vascular endothelial regeneration as well as differentiation of endogenous neural cells [22-25]. In addition, in the NCAs group there was a tendency to a lower percentage of LSA than in the $1^{\text {st }}$ control $(p=0.050 ; a=0.017)$ (Fig. 12).

The distance from the damage border to the nearest neurons (DDNN).

The morphological research of a zone adjacent to ICH helps to define

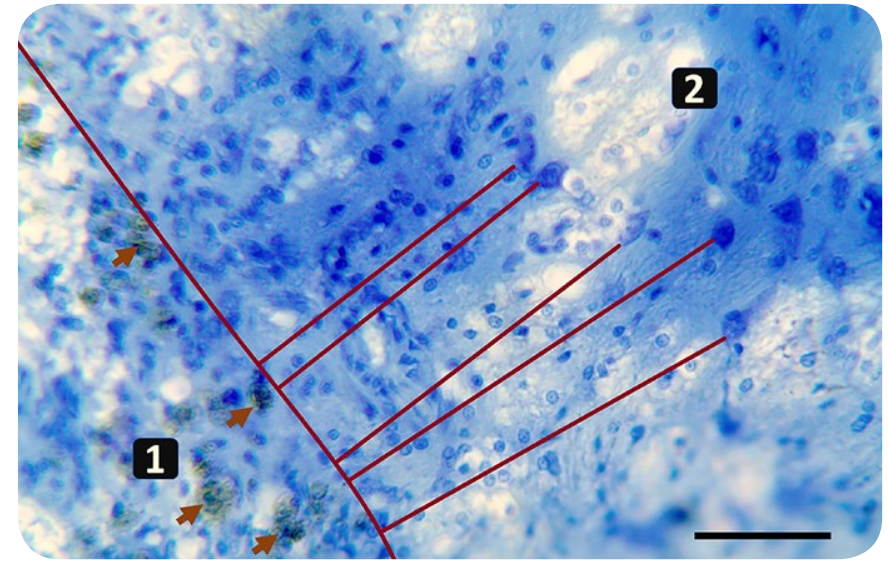

A Fig. 13. Determination of the average distance from the border of the lesion to the nearest neurons in a striatum (red lines): 1 - the damaged area of a striatum; 2 - the intact area of the striatum. The arrows indicate hemosiderin granules. Nissl staining; scale bar $-50 \mu \mathrm{m}$.

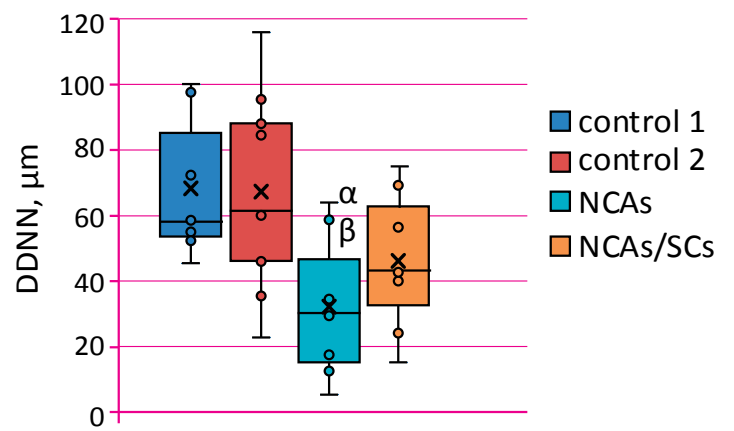

A

Fig. 14. The distance from the border of lesion to the nearest neurons in the brain of rats of experimental groups on the $42^{\text {nd }}$ day after ICH. Notes: a-represents significant difference from the $1^{\text {st }}$ control group $(p=0.008)$, Dunn's test; $\beta$ - represents significant difference from the $2^{\text {nd }}$ control group $(p=0.01)$, Dunn's test.

the border of a lesion area along the line through the outermost grains of hemosiderin (Fig. 11, 13).

On the $42^{\text {nd }}$ day, when comparing all groups with each other in the Kruskal-Wallis test statistically significant differences $(p=0.047)$ were found. In NCAs rat group, significantly lower DDNN was detected than in the $1^{\text {st }}$ and $2^{\text {nd }}$ control groups ( $p=0.008$ and $p=0.010$, respectively; $a=0.017$ ), which indicates a decrease in the influence of adverse factors and more efficient regeneration of neurons in areas adjacent to the site of hemorrhage in rats injected with NCAs (Fig. 14).

The absence of significant changes in the group of NCAs administration combined with fetal liver SCs may be due to incomplete clearance of ICH areas from detritus, which inhibits regeneration as a result of antiinflammatory effects of SCs [20], or random variation (difference between NCAs and NCAs/SCs groups is not statistically significant). To date, other authors have not conducted a comparative study of the effectiveness of NCAs or neurospheres in combination with SCs. According to our study, the administration of NCs in the aggregates, both alone and in combination with SCs, promote to reduce oxidative stress and preserve the tissue of the striatum and neurons near the injured area. The presence of positive changes may be due to paracrine, neuroprotective and angiogenic effects of injected cells $[22,23]$, as well as their anti-inflammatory properties [24, 25]. 


\section{CONCLUSION}

1. The administration of neural cell aggregates to rats with the model of intracerebral hemorrhage, both alone and in combination with fetal liver stromal cells, reduces oxidative stress and preserves striatum and neuron tissue near the lesion area.

2. The co-transplantation of fetal liver stromal cells with neural cell aggregates was accompanied by an earlier and longer significant decrease in lipid peroxidation and lactate dehydrogenase activity in rat blood at the $14^{\text {th }}$ day after intracerebral hemorrhage, but had no advantages by morphometric studies of brain at $42^{\text {nd }}$ day over single administration of neural cell aggregates.

\section{REFERENCES:}

1. Poon MT, Fonville $A F$, Al-Shahi Salman R. Long-term prognosis after intracerebral haemorrhage: systematic review and meta-analysis. $J$ Neurol Neurosurg Psychiatry 2014; 85(6):660-667.

2. Detante O, Jaillard A, Moisan A, et al. Bioterapies in stroke. Rev Neurol. 2014; 170: 779-798.

3. Sukach AN, Lebedinsky AS, Otchenashko OV, et al. Transplantation of cryopreserved rat fetal neural cells in suspension and in multicellular aggregates into rats with spinal cord injury. Cell Organ Transpl. 2016; 4(1):22-28. DOl: 10.22494/COT.V4l1.5

4. Zolotko KM, Sukach AN, Kompaniets AM. [The dynamics of behavioral tests in rats with intracerebral hemorrhage after the injection of cryopreserved neural cells]. Visnyk problem biologii i medytsyny. 2019; 3(152):108-112. DOl: 10.29254/2077-4214-2019-3-152-108-112. [In Russian].

5. Prockop DJ, Oh JY. Mesenchymal stem/stromal cells (MSCs): role as guardians of inflammation. MolTher. 2012; 20(1):14-20. D0l: 10.1038/mt.2011.211.

6. MacLellan CL, Silasi G, Poon CC, et al. Intracerebral hemorrhage models in rat: comparing collagenase to blood infusion. J Cereb Blood Flow Metab. 2008; 28:516525. DOl:10.1038/sj.jcbfm.9600548.

7. Chen AZ, Liu N, Huang $\mathrm{H}$, et al. Outgrowth of neuronal axons on adipose-derived stem cell transplanting for treatment of cerebral infarction in rats. Cell Mol Immunol. 2011; 27(8):868-871.

8. Nonaka $M$, Yoshikawa $M$, Nishimura $F$, et al. Intraventricular transplantation of embryonic stem cell-derived neural stem cells in intracerebral hemorrhage rats. Neurol Res. 2004; 26(3): 265-272. DOI: 10.1179/016164104225014049

9. Sukach OM. Inventor Institute for problems of cryobiology and cryomedicine National academy of sciences of Ukraine, assignee. [The method of neural precursor cells obtaining]. Patent of Ukraine 119411. 2017 September 25. [In Ukrainian].

10. Sukach AN, Shevchenko MV, Liashenko TD. Comparative study of influence on fetal bovine serum and serum of adult rat on cultivation of newborn rat neural cells. Biopolym Cell. 2014; 30(5):394-400.

11. Sukach AN, Liashenko TD, Shevchenko MV. [Properties of the isolated cells of newborn rats' nervous tissue in culture]. Biotechnol Acta. 2013; 6(3):63-68. [In Russian].

12. Petrenko $A Y u$, Sukach AN. Isolation of intact mitochondria and hepatocytes using vibration. Analytical Biochem. 1991; 194(2):326-29.

13. Hoppo T, Fujii H, HiroseT, et al. Thy1-positive mesenchymal cells promote the maturation of CD49f-positive hepatic progenitor cells in the mouse fetal liver. Hepatology. 2004; 39:1362-70.

14. Schmelzer E. Zhang L, Bruce A, et al. Human hepatic stem cells from fetal and postnatal donors. J Exp Med. 2007; 204:1973-87.

15. Han N, Ding S, Wu T, Zhu Y. Correlation of free radical level and apoptosis after intracerebral hemorrhage in rats. Neurosci Bull. 2008; 24(6):351-358. D0l: 10.1007/s12264-008-0711-4.

16. Wang G, Yang Q, Li G, Wang L, Hu W, Tang, et al. Time course of heme oxygenase- 1 and oxidative stress after experimental intracerebral hemorrhage. ActaNeurochir. 2011; 153(2):319-325.DOI: 10.1007/s00701-010-0750-2.

17. Andreeva $L N$. Modifikatsiya metoda opredeleniya perekisey lipidov $v$ teste $s$ tiobarbiturovoy kislotoy. [Modification of the method for determining lipid peroxides in the test with thiobarbituric acid]. Laboratornoe delo - Laboratory work. 1988; 11:41-43. [In Russian].

18. Glantz S. Mediko-biologicheskaya statistika [Biomedical statistics]. Moskva: Praktika - Moscow: Practice. 1998, 459 p. [In Russian].

19. Pohlert T. The pairwise multiple comparison of mean ranks package (PMCMR). R package. New York: CRAN.R-project, 2016.

20. Ross MH, Pawlina W. Histology. A text and atlas with correlated cell and molecular biology. 7th ed. Gainseville: WoltersKluwerl; 2016. $1002 \mathrm{p}$

21. Beray-Berthat $V$, Delifer $C$, Besson VC, et al. Long-term histological and behavioral characterization of a collagenase-induced model of intracerebral haemorrhage in rats. J Neurosci Methods. 2010; 191:180-190.

22. Donatella $D F$, Merlini A, Laterza $C$, Martino G. Neural stem cell transplantation in central nervous system disorders: from cell replacement to neuroprotection. Curr Opin Neurol. 2012; 25(3):322-333.

23. Hagg T. From neurotransmitters to neurotrophic factors to neurogenesis. The Neuroscientist. 2009; 15(1):20-27. D0I: 10.1177/1073858408324789.

24. Matarredona ER, Talaverón R, Pastor AM. Interactions between neural progenitor cells and microglia in the subventricular zone: physiological implications in the neurogenic niche and after implantation in the injured brain. Front Cell Neurosci. 2018; 12:268. DOl: 10.3389/fncel.2018.00268.

25. Marques BL, Carvalho GA, Freitas EM, et al. The role of neurogenesis in neurorepair after ischemic stroke. 2018. Available from: http://doi.org/10.1016/j. semcdb.2018.12.003.

artict

The authors declared no potential conflicts of interest with respect to the research, authorship, and/or publication of this article. 


\section{Ефективність застосування агрегатів фетальних нейральних клітин та їх комбінації зі стромальними клітинами фетальної печінки для зменшення пошкодження мозку після інтрацеребрального крововиливу у щурів}

Золотько К. М. ${ }^{1}$, Сукач О. М. ${ }^{1,2}$, Компанієць А. М.

${ }^{1}$ Інститут проблем кріобіології і кріомедицини Національної академії наук України, Харків, Україна

${ }^{2}$ Харківський педагогічний університет ім. Г. С. Сковороди, Харків, Украйна

\section{PEЗЮME}

Пацієнти з інтрацеребральним крововиливом мають часті ускладнення і високий рівень смертності. Ефективних методів лікування цього захворювання на даний час не існує. Нами було досліджено вплив застосування кріоконсервованих агрегатів нейральних клітин сумісно з стромальними клітинами фетальної печінки на зменшення пошкодження мозку щурів після інтрацеребрального крововиливу.

МАТЕРІАЛИ ТА МЕТОДИ. Інтрацеребральний крововилив моделювали шляхом стереотаксичного введення 0,2 0Д колагенази IV типу у стріатум щурів. Нейральні клітини виділяли з головного мозку, а стромальні - з печінки плодів щурів 15-16-ї доби гестації. Суспензію агрегатів нейральних клітин (АНК) окремо та в комбінації зі стромальними клітинами фретальної печінки (СК) вводили у боковий шлуночок мозку. Рівень перекисного окислення ліпідів визначали по вмісту активних продуктів тіобарбітурової кислоти. Ступінь пошкодження клітин головного мозку після крововиливу визначали по активності лактатдегідрогенази у сироватці крові. Для оцінювання інтенсивності дії несприятливих факторів та регенеративного потенціалу різних варіантів клітинної терапії визначали площу втраченого стріатуму у мозку щурів та середню відстань від межі пошкодження до найближчих нейронів.

РЕЗУЛЬТАТИ. Було встановлено, що введення АНК спільно з СК щурам з інтрацеребральним крововиливом більш ефективно зменшуе концентрацію малонового діальдегіду та активність лактатдегідрогенази, порівняно з введенням одних лише АНК, що свідчить про пригнічення інтенсивності перекисного окислення ліпідів та пошкодження клітин після інтрацеребрального крововиливу в результаті додавання СК. Спостерігалось значуще зменшення площі втраченого стріатуму у обох дослідних групах. Було показано, що ізольоване введення АНК в більшій мірі зменшувало відстань від межі пошкодження до найближчих нейронів, що свідчить про створення кращих умов для виживання та/або регенерації нейронів у близькості до зони ураження порівняно з контролем.

ВИсновки. Введення АНК як ізольовано так і в комбінації з СК сприяє зменшенню інтенсивності оксидативного стресу, збереженню об'єму непошкодженої тканини стріатуму та збільшенню кількості нейронів у безпосередній близькості до зони ураження мозку при інтрацеребральному крововиливі у щурів. Додавання СК сприяє більш ефеккивному пригніченню перекисного окислення ліпідів.

кЛЮчовІ СЛовА: інтрацеребральний крововилив; агрегати нейральних клітин; стромальні клітини феетальної печінки; стереотаксис 